\title{
HUBUNGAN PENGETAHUAN SISWA TENTANG KESEHATAN MATA DENGAN SIKAP PENGGUNAAN GADGET YANG BERLEBIHAN DI SD N 13 ENGKASAN KALIMANTAN BARAT
}

The Correlation Between Student Knowledge About Eye Health And Excessive Gadget Use Behaviour At SD N 13 Engkasan, West Kalimantan

\author{
Agnes Dwiana ${ }^{1}$, Cici Lestari ${ }^{2}$, Lina Astuty ${ }^{3}$ \\ 1,2,3 Akademi Kebidana St. Benedicta Pontianak \\ agnes.benedict4@gmail.com
}

\begin{abstract}
ABSTRAK
Latar Belakang : Data WHO, ada lebih dari 285 juta penduduk dunia mengalami gangguan penglihatan dan 39 juta diantaranya mengalami kebutaan, 124 juta dengan low vision serta 153 juta mengalami gangguan penglihatan karena kelainan refraksi. Jika kebiasaan menggunakan Gadget dalam waktu yang lama dan terus menerus ini dibiarkan akan memberikan dampak negatif bagi indra penglihatan. Usia anak merupakan masa pertumbuhan, jika terlalu lama menggunakan gadget bisa berpengaruh pada penglihatan.

Tujuan : Penelitian ini bertujuan untuk mengetahui hubungan pengetahuan siswa kelas III SD tentang kesehatan mata dengan sikap penggunan gadget yang berlebihan di SDN 13 Engkasan Kecamatan Tayan Hulu Kabupaten Sanggau Kalimantan Barat.

Metode : Penelitian ini menggunakan metode deskriptif analitik dengan pendekatan cross sectional. Jumlah responden 55 orang menggunakan teknik total sampling. Instrumen penelitian yang digunakan adalah kuesioner dan analisis data menggunakan uji Chi Square.

Hasil Penelitian : Hasil Uji Chi Square adalah sig $=0.000<0,05$, bedasarkan hasil penelitian diketahui bahwa sebagian besar dari responden memiliki pengetahuan yang cukup yaitu 30 orang $(54,54 \%)$, mayoritas responden mempunyai sikap yang positif sebanyak 36 orang $(65,45 \%)$.

Simpulan : Terdapat hubungan yang signifikan pada pengetahuan siswa tentang kesehatan mata dengan sikap penggunan gadget yang berlebihan dengan nilai sig $=0.000<0.05$
\end{abstract}

Kata Kunci : Pengetahuan, Sikap, Kesehatan Mata, Penggunaan gadget.

\section{ABSTRACT}

Background: According to WHO, there are more than 285 million people in the world who experienced visual impairment and 39 million of them are blind, 124 million with low vision and 153 million have visual problems due to refractive errors. If the habit for long duration used of gadget continuously is allowed, it may impact on the sense of sight in negative way. Children's age is a period of growth, if they use gadgets for too long it can affect their vision. 
Agnes Dwiana, Cici Lestari, Lina Astuty (Hubungan Pengetahuan Siswa Tentang Kesehatan Mata Dengan Sikap Penggunaan Gadget Yang Berlebihan Di Sd N 13 Engkasan Kalimantan Barat)

The aim : This study aim to investigate the correlation between student knowledge about eye health and excessive gadget used behavior at SDN 13 Engkasan, West Kalimantan.

Method: This is a descriptive study which used cross-sectional design. The number of respondent are 55 students using a total sampling technique. This study used questionnaire as a tool and the data analysis is through Chi Square test.

Result: the result of Chi Square test is sig $p=0.000<0.05$. The data shows that the majority of respondents have sufficient knowledge, that is 30 people (54.54\%), and most of the respondents show positive behaviour for 36 people $(65.45 \%)$.

Conclusion: there is a significant correlation on student knowledge about eye health and the excessive gadget used behavior.

Keywords: Knowledge, Behaviour, Eye health, Gadget used.

\section{PENDAHULUAN}

Data WHO, ada lebih dari 285 juta penduduk dunia mengalami gangguan penglihatan dan 39 juta diantaranya mengalami kebutaan, 124 juta dengan low vision serta 153 juta mengalami gangguan penglihatan karena kelainan refraksi yang tidak terkoreksi. Sebanyak 90 persen penyandang gangguan penglihatan dan kebutaan ini hidup di negara dengan pendapatan rendah, yang jika dibiarkan begitu saja tanpa ada tindakan apapun, maka jumlah penderita gangguan penglihatan dan kebutaan ini akan membengkak menjadi dua kali lipat pada tahun 2020 ( WHO, 2018).

Usia anak merupakan masa pertumbuhan, jika terlalu lama menggunakan gadget bisa berpengaruh pada penglihatan. Pada kondisi seperti itu rentan terjadi astenopia atau mata lelah. Jika tidak segera diantisipasi, hal itu bisa merusak saraf retina. Dampak penggunaan gadget yang berlebihan menyebabkan mata lelah. Selain itu, efek radiasi gadget juga berpengaruh besar pada saraf mata kalau sudah terkena retina berbahaya. Untuk mendeteksi astenopia biasanya mata berair, merah, dan pusing karena kelelahan. Menurutnya, hal itu masih bisa diantisipasi dengan pengobatan. Di samping itu, asupan makanan yang kaya gizi juga penting untuk menunjang mata lelah ( Wong, 2010)

Deputi Tumbuh Kembang Anak, Kementerian Pemberdayaan Perempuan dan Perlindungan Anak RI, Leni Rosaline mengatakan, di Indonesia sekitar 10 persen dari 66 juta anak usia sekolah (5-19 tahun), mengalami gangguan mata akibat kelainan refraksi. Sekitar 4,6 persen dari total populasi penduduk Indonesia memakai kacamata refraksi dan lensa mata, atau dengan kata lain kacamata minus. Sekitar 90 persen dari kasus gangguan penglihatan ini diderita oleh keluarga dari masyarakat berpenghasilan rendah (Riskesdas, 2013). Prevalensi gangguan penglihatan menurut Riskesdas Tahun 2013, diperkirakan 0,4\% penduduk Indonesia mengalami kebutaan atau gangguan penglihatan, Sebanyak 80 persen penyandang gangguan penglihatan dan kebutaan dapat dicegah bahkan diobati. Data ini mendasari fokus program penanggulangan gangguan penglihatan dan kebutaan di Indonesia, pada penanggulangan katarak dan gangguan 
penglihatan dengan penyebab lainnya. Dinas Kesehatan Kalimantan Barat mencatat 10 persen dari jumlah anak sekolah mengalami gangguan penglihatan. Dinas Kesehatan Kabupaten Sanggau mencatat pada awal kegiatan pemeriksaan mata tahun 2011, hampir sekitar 30\% hasilnya siswa mengalami gangguan penglihatan jarak jauh (minus) (Dinkes Kabupaten Sanggau, 2011).

Handphone merupakan salah satu barang canggih (gadget) yang menyajikan berbagai aplikasi baik itu jejaring sosial, media berita dan juga hiburan bagi para pengguna (Harfiyanto, 2015). Gadget mempunyai banyak manfaat yang diberikan bagi pengguna. Dampak positif yang diberikan kepada pengguna hp yaitu para pengguna mudah mendapatkan informasi terbaru dengan mengakses internet dan aplikasi lainnya. Dampak negatif dari pengunaan Gadget yaitu menurunnya fungsi penglihatan, mata menjadi kering, kepala sakit dan air mata selalu keluar akibat paparan sinar dari layar monitor $(L E D / L C D)$ dan penyinaran lainnya akan berdampak buruk terhadap kesehatan mata salah satunya yaitu penurunan ketajaman penglihatan (Widea, 2015).

Pada masa kini anak-anak sudah diberikan gadget dan mereka diberi kebebasan untuk menggunakan gawai, padahal pengenalan gadget pada anak saat usia sekolah dianggap terlalu dini. Pada saat ini banyak anak yang mengalami kerusakan mata di usia dini. Pemakaian gadget dalam durasi yang lama, posisi tubuh yang kurang baik saat menggunakan gawai dan kurangnya intensitas cahaya dianggap sebagai penyebab dari penurunan ketajaman penglihatan anak (Widea, 2015).

Kebiasaan menggunakan gadget dalam jangka waktu yang lama merupakan kebiasaan yang kurang baik. Jika kebiasaan menggunakan Gadget dalam waktu yang lama dan terus menerus ini dibiarkan akan memberikan dampak negatif bagi indra penglihatan. Menatap layar gawai dalam waktu yang lama dapat memberikan tekanan tambahan pada mata dan susunan syaraf (Sindhi , 2013).

Hasil study pendahuluan yamg dilakukan peneliti pada tanggal 2 Januari 2020 , diperoleh hasil wawancara dengan Bapak Kepala Sekolah mengatakan meskipun saat di sekolah siswa-siswi tidak diperbolehkan membahawa gadget, hampir semua anak SDN 13 Engkasan menggunakan gadget saat dirumah dan terdapat 6 orang memakai kaca mata. Peneliti melakukan wawancara dengan 5 orang para siswa terdiri dari 2 laki-laki, 3 perempuan, peneliti menanyakan 5 pertanyaan yang sama kepada siswa dan siswi tentang kesehatan mata, dampak penggunan gadget yang berlebihan terhadap kesehatan mata, lama penggunaan gadget dalam sehari, cara menjaga kesehatan mata, jarak layar gadget dengan mata. 3 orang siswa menjawab tidak tahu tentang kesehatan mata dan bahaya penggunaan gadget yang berlebihan. Bertolak dari latar belakang tersebut maka peneliti tertarik untuk mengetahui hubungan pengetahuan siswa tentang kesehatan mata dengan sikap penggunaan gadget berlebihan di SDN 13 Engkasan Kecamatan Tayan Hulu Kabupaten Sanggau Tahun 2020. 


\section{METODE PENELITIAN}

Jenis penelitian ini adalah survey deskriptif dengan pendekatan cross sectional. Alat pengumpulan data menggunakan kuesioner. Populasi dalam penelitian ini adalah seluruh siswa-siswi kelas III SD Negeri 13 Engkasan yang berjumlah 55 orang. Teknik pengambilan sampel menggunakan teknik total sampling sehingga diperoleh 55 orang. Instrumen dalam penelitian ini menggunakan kuesioner. Pengukuran data yang digunakan dalam kuesioner ini adalah Skala Guttman dan Skala Likert. Metode pengumpulan data menggunakan data primer dan data sekunder. Pengambilan data primer dilakukan dengan membagikan kuesioner kepada responden, sebelum mengisi kuesioner responden diberi penjelasan tentang cara mengisi kuesioner dan selanjutnya memberikan informed consent yang diikuti penyerahan kuesioner. Setelah kuesioner diterima oleh responden, responden langsung mengisi kuesioner yang diberikan sesuai dengan ketentuan yang ada. Selanjutnya kuesioner dikumpulkan oleh peneliti untuk diperiksa kelengkapan jawaban, bila kurang lengkap dikembalikan pada responden untuk dilengkapi. Data sekunder berupa daftar nama siswa pada bulan Maret tahun 2020. Teknik pengolahan data dalam penelitian ini adalah editing, codding sheet, data entry, dan tabulating. Analisa data dalam penelitian ini menggunakan uji chi kuadrat.

\section{HASIL DAN PEMBAHASAN}

Tabel 1 Distribusi Frekuensi Responden Menurut Usia

\begin{tabular}{ccc}
\hline Usia & frekuensi (f) & Prosentase (\%) \\
\hline 9 Tahun & 7 & 13 \\
10 Tahun & 25 & 45 \\
11 Tahun & 15 & 27 \\
12 Tahun & 8 & 15 \\
Jumlah & 55 & 100 \\
\hline
\end{tabular}

Berdasarkan diatas menunjukan bahwa sebagian besar dari responden yaitu 25 responden ( $45 \%$ ) berumur 10 tahun.

Tabel 2 Distribusi Frekuensi Responden Tentang Pengertian Kesehatan Mata

\begin{tabular}{ccc}
\hline Tingkat Pengetahuan & frekuensi (f) & Prosentase (\%) \\
\hline Baik & 11 & 20 \\
Cukup & 30 & 55 \\
Kurang & 14 & 25 \\
Jumlah & 55 & 100 \\
\hline
\end{tabular}

Berdasarkan diatas diperoleh data dari 55 responden, menunjukan bahwa sebagian besar dari responden memiliki pengetahuan cukup tentang kesehatan mata yaitu sebanyak 30 responden 55 . 
Agnes Dwiana, Cici Lestari, Lina Astuty (Hubungan Pengetahuan Siswa Tentang Kesehatan Mata Dengan Sikap Penggunaan Gadget Yang Berlebihan Di Sd N 13 Engkasan Kalimantan Barat)

Tabel 3 Distribusi Sikap Anak SD Kelas III Tentang Penggunan Gadget yang Berlebihan Di SDN 13 Engkasan Tahun 2020

\begin{tabular}{ccc}
\hline Sikap & frekuensi (f) & Prosentase (\%) \\
\hline Positif & 36 & 64,45 \\
Negatif & 19 & 34,55 \\
Jumlah & 55 & 100 \\
\hline
\end{tabular}

Berdasarkan diatas diperoleh data dari 55 responden, menunjukan bahwa sebagian besar dari responden memiliki sikap yang positif tentang penggunaan gadget yang berlebihan yaitu sebanyak 36 responden.

Tabel 4 Distribusi Frekuensi Pengetahuan Tentang Kesehatan Mata

\begin{tabular}{lcccccc}
\multirow{2}{*}{$\begin{array}{c}\text { Pengetahuan } \\
\text { tentang } \\
\text { kesehatan mata }\end{array}$} & \multicolumn{2}{c}{ Sikap penggunan Gadget yang Berlebihan } & \multicolumn{2}{c}{ Total } \\
\cline { 2 - 6 } & \multicolumn{2}{c}{ Positif } & \multicolumn{2}{c}{ Negatif } & & \\
\cline { 2 - 6 } & $\mathrm{N}$ & $\%$ & $\mathrm{~N}$ & $\%$ & $\mathrm{~N}$ & $\%$ \\
\hline Baik & 7 & $53,8 \%$ & 6 & $46,2 \%$ & 13 & $100 \%$ \\
Cukup & 28 & $100 \%$ & 0 & $0 \%$ & 28 & $100 \%$ \\
Kurang & 1 & $7.1 \%$ & 13 & $92,9 \%$ & 14 & $100 \%$ \\
Total & 36 & $65,5 \%$ & 19 & $34,5 \%$ & 55 & $100 \%$ \\
\hline
\end{tabular}

Untuk mengetahui ada tidaknya hubungan pegetahuan siswa-siswi kelas III SD tentang kesehatan mata dengan sikap penggunan gadget yang berlebihan di SDN 13 Engkasan tahun 2020. Dilakukan analisis data dengan computer menggunakan aplikasi SPSS versi 20.0 untuk menghitung rumus Chi-Square sehingga didapatkan adanya hitungan yaitu cara 1 : nilai sig adalah $0,00<0,05$ maka Ho ditolak, cara 2 : nilai : $X^{2}$ hitung 36,605> 5,991 maka Ho ditolak, artinya terdapat hubungan pengetahuan siswa siswi kelas III SD tentang kesehatan mata dengan sikap penggunan gadget yang berlebihan di SDN 13 Engkasan. Hal ini sesuai dengan hipotesis penelitian yaitu ada hubungan antara pengetahuan siswa siswi kelas III SD tentang kesehatan mata dengan sikap penggunan gadget yang berlebihan. Berdasarkan analisis data yaitu hasil uji Chi-Square diperoleh hasil table terdapat 2 cell $(33,3 \%)$ yang nilai harapanya kuang dari 5 tidak memenuhi syarat maka dilakukan uji alternatif kolmogorov-smirnov.

Setelah dilakukan Uji alternatif kolmogorov-simrnov, ternyata memenuhi syarat dengan jumlah didapatkan sig $=0,00$ dengan $\mathrm{p}<0,05$ sehingga dapat disimpulkan bahwa terdapat hubungan antara pengetahuan siswa-siswi kelas III SD tentang kesehatan mata dengan penggunaan gadget yang berlebihan di SDN 13 Engkasan

Pengetahuan adalah merupakan hasil "tahu" dan ini terjadi setelah orang mengadakan penngindraan terhadap suatu objek tertentu. Pengindraan terhadap objek terjadi melalui panca indra manusia, yaitu penglihatan, pendengaran, penciuman, rasa, dan raba dengan sendiri. Pada waktu pengindraan sampai 
menghasilkan pengetahuan tersebut sangat dipengaruhi oleh intensitas perhatian persepsi terhadap objek. (Notoatmodjo, 2017).

Berdasarkan tabel 2 menunjukkan bahwa sebagian dari responden memiliki pengatahuan cukup tentang Kesehatan Mata dan peggunaan gadget yang berlebihan yaitu sebanyak 30 responden $(54,54 \%)$. Dari hasil penelitian ini didaptkan bahwa siswa-siswi cukup memahami tentang kesehatan mata dan penggunan gadget yang berlebihan tetapi masih perlu ditingkatkan lagi tingkat pengetahuan mengenai kesehatan mata dan penggunan gadget yang berlebihan dengan berbagai informasi dari tenaga kesehatan atau dari media masa guna untuk meningkatkan tingkat pengetahuan manjadi baik. Didukung dengan teori Notoatmodjo (2017), Informasi yang diperoleh baik dari pendidikan formal maupun non formal dapat memberikan pengaruh jangka pendek sehingga menghasilkan perubahan atau peningkatan pengetahuan. Majunya teknologi akan membuat tersedianya bermacam-macam media masa yang dapat mempengaruhi pengatahuan masyarakat tentang inovasi baru. Adanya informasi baru dapat terbentuknya pengetahuan terhadap hal tersebut.

Sikap adalah cara atau menempatkan membawa diri atau merasakan jalan pikiran dan prilaku menurut A.Wawan dan Dewi (2011). Berdasarkan tabel 4.4 menunjukkan bahwa sebagian besar dari responden sebanyak 37responden memiliki sikap positif $(67,27 \%)$ terhadap penggunan gadget yang berlebihan. Siswa-siswi SDN 13 Engkasan memiliki sikap yang bervariasi yaitu positif dan negatif. Sikap sesorang terhadap objek mempunyai respon yang berbeda-beda.

Menurut Manumpil, dkk (2015) sikap positif kecenderungan tindakan adalah mendekati, menyenangi, mengharapkan objek tertentu dan sikap negatif terdapat kecenderungan untuk menjauhi, menghindari, membenci, tidak menyukai objek tertentu.

Berdasarkan hasil uji dengan menggunakan Chi-Square menunjukan adanya hubungan yang bermakna bagi pengetahuan siswa-siswi kelas III SD tentang kesehatan mata dengan sikap penggunan gadget yang berlebihan. Hal ini ditunjukan dengan nilai $X^{2}$ hitung $12,783>X^{2}$ tabel 5,991 maka Ho ditolak dan Ha diterima artinya terdapat hubungan pengetahuan siswa-siswi kelas III SD tentang kesehatan mata dengan sikap penggunan gadget yang berlebihan. Berdasarkan hasil yang didapatkan peneliti menunjukan ada " hubungan pengetahuan siswa-siswi kelas III SD tentang kesehatan mata dengan penggunaan gadget yang berlebihan di SDN 13 Engkasan tahun 2020”. Karena pada penelitian ini diperoleh hasil bahwa sebagian besar responden memiliki penegtahuan cukup tentang kesehatan mata dengan sikap positif terhadap penggunan gadget yang berkebihan, dimana prilaku seseorang dipengaruhi oleh faktor predisposisi yang mempermudah terjadinya prilaku seseorang seperti pengetahuan, sikap keyakinan , kepercayaan, tradisi, nilai-nilai dan unsur-unsur lain (Notoatmojo, 2017)

Berdasarkan Tabel 1 menunjukan bahwa sebagian kecil dari responden yaitu 25 responden $(45,45 \%)$ berumur 10 tahun, hal ini dapat berpengaruh pada pengetahuan dan sikap sesuai teori Notoatmodjo (2017) mengatakan semakin cukup umur, tingkat kematangan dan kekuatan sesorang akan lebih matang dalam berfikir dan bekerja. Segi kepercayaan masyarakat yang lebih dewasa dipercayai 
dari orang yang belum tinggi kedewasaannya. Hal ini sebagai pengalaman dan kematangan jiwa.

Peneliti berasumsi bawa umur siswa-siswi sangat berpengaruh pada pengetahuan maupun sikap dalan menggunakan gadget karena semakin tua umur maka pengetahuan dan sikap akan baik, dapat mengatur waktu penggunan gadget dan apabila umur sesorang terlalu muda maka seseorang belum berfiki terlalu matang tentang sesuatu hal yang mempengaruhinya, seperti penggunan gadget yang berlebihan dapat berpengaruh bagi kesehatan mata.

Penelitian ini juga selaras dengan hasil penelitian sebelumnya oleh Rahmawaty (2018) ada hubungan penggunaan gadget dengan ketajaman penglihatan pada siswa, responden mengalami perubahan ketajaman penglihatan dengan penggunaan gadget, ketajaman penglihatan responden rendah. Selain itu, penelitian terdahulu yang dilakukan oleh Nur Muallima, dkk (2019) didapatkan hasil penelitian bahwa terdapat hubungan signifikan antara variabel durasi penggunaan gadget dengan penurunan tajam penglihatan, terdapat hubungan signifikan antara variabel frekuensi penggunaan gadget dengan penurunan tajam penglihatan dengan nilai $\mathrm{P}=0,000(0,05)$, dan terdapat hubungan signifikan antara variabel jarak penggunaan gadget dengan penurunan tajam penglihatan dengan nilai $\mathrm{P}=0,001(0,05)$.

\section{SIMPULAN DAN SARAN}

\section{Simpulan}

Mayoritas dari responden yaitu 25 responden (45,45\%) berumur 10 tahun. Pengetahuan responden tentang kesehatan mata dan sikap penggunan gadget yang berlebihan secara umum sebanyak 30 siswa-siswi berpengetahuan cukup $(54,54 \%)$. Sikap terhadap penggunan gadget yang berlebihan terdapat 36 anak memiliki sikap positif $(65,45 \%)$. Pada uji statistik dengan menggunakan ChiSquare menunjukan adanya hubungan yang bermakna dengan nilai $\mathrm{X}^{2}$ hitung12,783 $>\mathrm{X}^{2}$ tabel 5,991 .

\section{Saran}

Diharapkan dengan adanya penelitian ini dapat meningkatkan pengetahuan siswa-siswi tentang pentingnya mengetahui kesehatan mata dengan menambah buku-buku bacaan dapat menjadi litelatur untuk menambah pengatahun mengenai penetahuan siswa-siswi tentang sikap penggunan gadget yang berlebihan dengan cara bekerjasama dengan tenaga kesehatan untuk dilakukan penyuluhan mengenai kesehatan mata, sehingga diharapkan siswa-siswi di SDN 13 memiliki pengetahuan yang baik mengenai kesehatan mata sehingga angka kejadian gangguan kesehataan mata usia dini yang di sebakan penggunan gadget yang berlebihan dapat berkurang. 


\section{DAFTAR PUSTAKA}

A.Wawan, Dewi. 2011. Teori \& Pengukuran Pengetahuan, Sikap, Dan Perilaku Manusia. Yogyakarta: Nuha Medika

Rahmawaty. 2018. Hubungan Penggunaan Gadget dengan Ketajaman Penglihatan Pada Siswa Kelas VII dan VIII. Skripsi STIKES ICME Jombang. http://repo.stikesicmejbg.ac.id/557/2/143210009\%20DEVY\%20RISTI YA\%20IRAWAN\%20RAHMAWATY\%20SKRIPSI.pdf diakses bulan Juli 2020.

Dinas Kesehatan Provinsi Kalimantan Barat. 2011. Profil Kesehatan Provinsi Kalimantan Barat. Kalimantan Barat : Dinas Kesehatan.

Widea, Ernawati. 2015. "Pengaruh Penggunaan Gadget Terhadap Penurunan Tajam Penglihatan Pada Anak Usia Sekolah (6-12 Tahun) Di Sd Muhammadiyah 2 Pontianak Selatan.": 5-6. https://jurnal.untan.ac.id/index.php/jmkeperawatanFK/article/view/1053 3 Diakses November 2020.

Harfiyanto, Doni, dkk.2015. Pola Interaksi Sosial Siswa Pengguna Gadget di SMA Negeri 1 Semarang. Semarang: Universitas Negeri Semarang. http://journal.Unnes.ac.id/sju/index.php/jess . Diakses Desember 2020.

Kemenkes RI. Laporan Hasil Riset Kesehatan Dasar (Riskesdas) Indonesia tahun 2013. Jakarta : Badan Penelitian dan Pengembangan Kesehatan Kemenkes RI; 2013.

Manumpil, dkk. 2015. "Hubungan Penggunaan Gadget Dengan Tingkat Prestasi Siswa Di SMA Negeri 9 Manado." ejournal Keperawatan (e-Kep)1-5. https://ejournal.unsrat.ac.id/index.php/jkp/article/view/7646 Diakses November 2020.

Muallima, Nur,dkk. 2019. Hubungan Penggunaan Gadget Dengan Penurunan Tajam Penglihatan Pada Siswa SMP UNISMUH Makassar. Jurnal Ilmiah Kesehatan Iqra. Volume 7 Nomor 2 Bulan Desember tahun 2019.e-issn : 2656-5471

Notoatmodjo, S. 2017. Promosi Kesehatan dan Perilaku Kesehatan. Jakarta: PT Rineka Cipta.

Sindhi, D. N. 2013. "Hubungan Frekuensi Bermain Game Online Pada Anak Usia Remaja. Jakarta: EGC.

Wong, D.L. (2010). Pedoman Nasional Tumbuh Kembang Anak. Jakarta : Gramedia. 